
\title{
PResercrch Suare \\ Impact of Bisphenol-A on the Spliceosome and Meiosis of Sperm in the Testis of Adolescent Mice
}

\author{
Yongjie Wang \\ University of Arkansas
}

Yanyan Wu

Shihezi University

Shilei Zhang (D 18331093220@163.com)

Shihezi University

\section{Research Article}

Keywords: bisphenol-A, testis, Synaptonemal complex protein 3 (SCP3), DNA damage, RNA-seq, spliceosome

Posted Date: October 21st, 2021

DOI: https://doi.org/10.21203/rs.3.rs-955875/v1

License: (c) (i) This work is licensed under a Creative Commons Attribution 4.0 International License. Read Full License 


\section{Abstract}

\section{Background}

Bisphenol-A (BPA) has estrogenic activity and adversely affects humans and animals' reproductive systems and functions. There has been a disagreement with the safety of BPA exposure at Tolerable daily intake (TDI) $(0.05 \mathrm{mg} / \mathrm{kg} / \mathrm{d})$ value and non-observed adverse effect level $(5 \mathrm{mg} / \mathrm{kg} / \mathrm{d})$. The current study investigated the effects of BPA exposure at various doses starting from Tolerable daily intake (0.05 $\mathrm{mg} / \mathrm{kg} / \mathrm{d})$ to the lowest observed adverse effect level $(50 \mathrm{mg} / \mathrm{kg} / \mathrm{d})$ on the testis development in male mice offspring. The BPA exposure lasted for 63 days from pregnancy day 0 of the dams to post-natal day (PND) 45 of the offspring.

\section{Results}

The results showed that BPA exposure significantly increased testis (BPA $\geq 20 \mathrm{mg} / \mathrm{kg} / \mathrm{d}$ ) and serum (BPA $\geq 10 \mathrm{mg} / \mathrm{kg} / \mathrm{d}$ ) BPA contents of PND 45 mice. The spermatogenic cells became loose, and the lumen of seminiferous tubules enlarged when BPA exposure at $0.05 \mathrm{mg} / \mathrm{kg} / \mathrm{d}$ TDI. BPA exposure at a low dose $(0.05 \mathrm{mg} / \mathrm{kg} / \mathrm{d})$ significantly reduced the expression of Scp3 proteins and elevated sperm abnormality. The significant decrease in Scp3 suggested that BPA inhibits the transformation of spermatogonia into spermatozoa in the testis. The RNA-seq proved that the spliceosome was significantly inhibited in the testes of mice exposed to BPA. According to the RT-qPCR, BPA exposure significantly reduced the expression of Snrpc (BPA $\geq 20 \mathrm{mg} / \mathrm{kg} / \mathrm{d}$ ) and Hnrnpu (BPA $\geq 0.5 \mathrm{mg} / \mathrm{kg} / \mathrm{d}$ ).

\section{Conclusions}

This study indicated that long-term BPA exposure at Tolerable daily intake $(0.05 \mathrm{mg} / \mathrm{kg} / \mathrm{d})$ is not safe because low-dose long-term exposure to BPA inhibits spermatogonial meiosis in mice testis impairs reproductive function in male offspring.

\section{Background}

Bisphenol-A (BPA) is an important derivative of phenol and acetone, and is widely used in the production of polymer materials such as polycarbonate, epoxy resin, polysulfone resin, polyphenylene ether resin, and unsaturated polyester resin. Additionally, BPA is also used to produce plasticizers, flame retardants, antioxidants, heat stabilizers, rubber antioxidants, pesticides, coatings, and other fine chemical products [1]. It is estimated that the annual global production of BPA is more than 6.8 million tons [2], whereas the annual production of BPA in China reached 1.41 million tons in 2016 [3]. BPA is a ubiquitous environmental endocrine disruptor with pseudo estrogen and antagonistic androgenic effects [4]. Studies have shown that a certain concentration of BPA exposure can seriously affect the development and function of the animal's reproductive system [5-7]. 
Further, BPA has been detected in landfill leachates, surface water in rivers [8-11], raw milk [12], infusion film bags [13], water bottle [14], canned beer and plastic bottled liquor [15]. Also, BPA was reported to be present in human body fluid samples such as blood, urine [16-18], newborn jaundice [19], saliva, amniotic fluid, and breast milk [20]. Recent studies revealed that BPA is present in indoor dust [21], and its content in the office room is 5 to 10 times more than that in the living room [22]. Increasing amounts of BPA are being released into the atmospheric environment especially in industrial areas and city centers [23].

Studies have shown that BPA exposure produces permanent deleterious effects on humans and animals' reproductive systems and functions [4]. Maternal bisphenol A exposure disrupts spermatogenesis in adult rat offspring [24]. Subjection to BPA causes deleterious effects such as nuclear DNA cleavage in germ cells and apoptosis in the testis in rats or mice $[25,26]$. Previous reports suggested that human health may be affected even with exposure to low levels of BPA [4]. Using a mice model to study BPA exposure effects on reproductive organs, RL Jones, SA Lang, JA Kendziorski, AD Greene and KAJEhp Burns [27] adopted the no-observed-adverse-effect-level (NOAEL) and the low-observed-adverse-effect-level (LOAEL) exposure levels. The NOAEL for BPA is $5 \mathrm{mg} / \mathrm{kg} /$ day, and LOAEL is $50 \mathrm{mg} / \mathrm{kg} /$ day suggested by US Environmental Protection Agency [17]. However, the detailed mechanism of BPA toxicology remains to be elucidated. BPA exposure via placenta first, and lactation and drinking water later, affected the body weight gain in male offspring at 45 postnatal days and the first round of spermatogenesis [28].

Synaptonemal complex protein 3 (Scp3) is a structural component of the synaptonemal complex, which was essential for meiosis [29]. Deleting the SCP3 gene would inhibit synaptosome formation and adversely influence the functions of DNA repair and recombinant proteins, resulting in the failure of meiosis and infertility in mice and humans [30,31]. Transcriptomic sequencing is often applied to differential gene screening and functional annotation [32]. Current methods for studying transcriptomes are primarily relying on sequencing techniques. In comparison with traditional analytical techniques, transcriptome sequencing analysis will obtain more comprehensive data [33].

The objective of this study was to evaluate the effects of BPA exposure through the placenta, lactation, and drinking water on testis development in male mice offspring by testing the histopathological changes of the testis, sperm quality, expression of SCP3 protein in spermatogenic cells, and by analyzing the testicular transcriptome data.

\section{Results}

\section{BPA contents in serum and testicular tissues}

The measurement results (Table 2) were conducted according to the manufacturer's instructions and considered credible when the linear regression coefficient was $R^{2} \geq 0.92$. The coefficient $R^{2}$ measured in our study was 0.9985 , implying credible results. The results showed that BPA content in the testis of PND 45 male mice was significantly higher than the control group $(1.23 \pm 0.12)$ when the BPA exposure dose 
was at or higher than $20 \mathrm{mg} / \mathrm{kg} / \mathrm{d}(2.17 \pm 0.12$ in group $\mathrm{F}$ and $2.67 \pm 0.20$ in group $\mathrm{G} ; P<0.05)$. Further, BPA content in serum reached significantly higher (in groups $E, F, G$ ) level than the control group when the BPA exposure dose was at or higher than $10 \mathrm{mg} / \mathrm{kg} / \mathrm{d}(P<0.05)$. Results indicate that BPA at higher doses can enter the testis.

\section{H\&E staining of testis}

The spermatogenic epithelium spermatogonia and basal lamina were intact or remained compact in the control group (Fig 1, A, marked by 1 and 2). The spermatogenic epithelium became loose, and the lumen of seminiferous tubules enlarged when the BPA exposure dose was at or higher than $0.05 \mathrm{mg} / \mathrm{kg} / \mathrm{d}$ (Fig 1 , $B \sim G$, marked by 4 and 5 ). Noticeable various spaces between the basal lamina and the spermatogonia were observed in BPA exposure groups (Fig 1, B G, indicated by 3). The basal lamina of PND 45 mice testis became incomplete (Fig 1, F G, marked by 6).

The seminiferous tubule cavities and epithelial height of testis were measured using Image $\mathrm{J}$. The results in Table 3 showed the lumen was enlarged significantly $(P<0.05)$ when BPA doses were at or higher than $0.05 \mathrm{mg} / \mathrm{kg} / \mathrm{d}(50.23 \pm 3.54)$ compared with the control group (37.26 \pm 5.32$)$. BPA exposure at or higher than $0.5 \mathrm{mg} / \mathrm{kg} / \mathrm{d}(37.03 \pm 2.10)$ reduced the epithelial height significantly $(P<0.05)$ compared with the control group (52.39 \pm 2.83$)$.

\section{Expressions of Scp3 in spermatogenic cells}

The Scp3 protein was expressed in the nucleus, and the expression of Scp3 was gradually decreased with the increase of BPA doses. Statistical analysis results revealed that expression levels of Scp3 protein in the bisphenol A exposed groups were significantly lower than those in the control group (Fig 2, Table 4). BPA exposure at a low dose $(0.05 \mathrm{mg} / \mathrm{kg} / \mathrm{d})$ significantly reduced the expression of Scp3 proteins. A significant difference was observed between the BPA $10 \mathrm{mg} / \mathrm{kg} / \mathrm{d}$ group and the BPA $20 \mathrm{mg} / \mathrm{kg} / \mathrm{d}$ group or BPA $50 \mathrm{mg} / \mathrm{kg} / \mathrm{d}$ group, suggesting a higher concentration of BPA causes more severe damages to the spermatogenic cells.

\section{DNA damages in mice sperm cells of different BPA treatment groups}

The comet assay visually revealed the DNA damages of the cells through the size of "tail". In this test, the DNA fragments "tail" of mice sperm cells became larger and larger as the increased doses of BPA (Fig. 3). The results implied that the BPA $\geq 0.5 \mathrm{mg} / \mathrm{kg} / \mathrm{d}$ induced significant damages to the spermatogenic cells (Table 5). 


\section{Effect of BPA on sperm count and sperm abnormality}

The sperm count was significantly reduced in BPA exposure groups (BPA囚0.5 mg/kg/d). The sperm abnormality rate of each BPA exposed group was significantly greater than that of the control group (Table 6).

\section{Effects of BPA on testicular gene expression in mice}

The BPA $50 \mathrm{mg} / \mathrm{kg} / \mathrm{d}$ group $(\mathrm{n}=3)$ and the control group $(\mathrm{n}=3)$ were subjected to transcriptome sequencing. The differential expressed genes from the sequencing results were introduced into the $G O$ terms and KEGG database for annotation analysis. The GO terms showed that the differential expressed genes are functionally categorized as genes of viral nucleocapsid, spermatid development, cytoplasm, and nucleus (Fig.4). The differential genes KEGG enrichment results showed that the shear metabolic pathway was significantly enriched (Fig. 5). The splicing U1 subunit protein C synthesis gene Snrpc and the cleavage universal vector component coding gene Hnrnpu were significantly down-regulated.

\section{Real-time PCR verification of the splicesome gene expression}

The expression levels of Snrpc and Hnrnpu in all 7 groups of testicular tissues were detected by real-time $\mathrm{PCR}$, and the error of RNA yield of different tissues was corrected by $\beta$-actin as an internal reference gene. The results showed that Snrpc and Hnrnpu decreased with the increase of BPA dosage, which was consistent with the transcriptome sequencing results. However, we can see that Hnrnpu is more sensitive to BPA by fluorescence quantitative PCR results. The expression of Hnrnpu decreased to less than half of the control group when the BPA dose was $0.5 \mathrm{mg} / \mathrm{kg} / \mathrm{d}$ or more, while the expression of Snrpc decreased to less than half of the control group when the BPA dose was $20 \mathrm{mg} / \mathrm{kg} / \mathrm{d}$ or more, Fig. 6 .

\section{Discussion}

BPA is an environmental endocrine-disrupting chemical widely used in the production of consumer products, with approximately $70 \%$ used to produce polycarbonate plastics for a variety of items [34]. Environmental Protection Agency, USA sets no observed adverse effect level (NOAEL) as BPA $5 \mathrm{mg} / \mathrm{kg} / \mathrm{d}$ and the low observed adverse effect level (LOAEL) as BPA $50 \mathrm{mg} / \mathrm{kg} / \mathrm{d}$ [27]. Studies showed that BPA could influence testicular development [35]. The contents of BPA in tissues were directly proportional to the exposure dose of BPA [36]. The sexual maturation in male mice was reported to be $36-46$ days (mean age: $40.6 \pm 0.6$ ) [37]. Therefore, the male offspring were sacrificed at PND 45 for measuring the various parameters indicating testis development.

In this study, the epithelial height of testis was significantly reduced in BPA groups (BPA at $\geq 0.5 \mathrm{mg} / \mathrm{kg}$ /d). The lumen of seminiferous tubules showed significant enlargement at the BPA exposure dose $\geq 0.05$ 
$\mathrm{mg} / \mathrm{kg} / \mathrm{d}$. Next, we tested sperm quality, including sperm count and abnormality rate. The results showed that $0.5 \mathrm{mg} / \mathrm{kg} / \mathrm{d}$ (lower than NOAEL) BPA significantly reduced the sperm count of the offspring male mice. This means that low BPA exposure, even at NOAEL level, could lead to lower sperm quality, which is consistent with the previous report [28].

We examined the expression of Scp3 in testicular spermatogenic cells to investigate the cause of the decrease in sperm count. The results showed that significantly reduced expression of Scp3 was observed when BPA exposure was at TDI value $(0.05 \mathrm{mg} / \mathrm{kg} / \mathrm{d})$. The TDI value of BPA was defined by the European Food Safety Authority [17]. Studies have shown that the lack of Scp3 can lead to impaired spermatogonial meiosis, leading to apoptosis [38]. To further validate the test results, we used the comet assay to determine the apoptosis of spermatogenic cells in the testes. The results showed that the BPA exposure dose at $0.5 \mathrm{mg} / \mathrm{kg} / \mathrm{d}$ (lower than NOAEL) resulted in the damage of germ cell nuclear DNA significantly greater than the control group $(P<0.05)$.

By GO terms and KEGG enrichment analysis of significantly differentially expressed genes, we found that the splicing function of mice testis was affected by the ingestion of BPA. The spliceosome is a ribonucleoprotein complex (snRNP) for removing pre-mRNA introns and converting them into mature mRNA. The snRNP was composed of five subunits (U1, U2, U4, U5, and U6) and more than 150 structural proteins [39]. In order to initiate the first step of splicing, it is needed to combine the U1 snRNP and universal protein components with the $5^{\prime}$ of mRNA [40]. In our present study, the heterogeneous nuclear ribonucleoprotein $\mathrm{U}(\mathrm{Hnrnpu})$ and the $\mathrm{U} 1 \mathrm{small}$ nuclear ribonucleoprotein $\mathrm{C}$ (Snrpc) were significantly down-regulated. The Snrpc is an essential component for the U1 subunit of the spliceosome, while Hnrnpu is an essential subunit for the hnRNPs, a common component protein of the spliceosome. The initial step in splicing is to make the $5^{\prime}$ splicing end of immature mRNA bind to U1 snRNP by the common component. Down-regulation of Snrpc and Hnrnpu makes the first step of post-transcriptional modification of mRNA impossible. Studies have shown that splice-associated proteins are highly expressed in spermatogonia, and alternative splicing is critical for mitotic to meiotic transition in mouse spermatogenesis [41]. RT qPCR results further confirmed that exposure to BPA reduced the expression of Snrpc and Hnrnpu in the testis, and Hnrnpu is more sensitive to BPA than Snrpc. Down-regulations of Hnrnpu and Snrpc made the first step of splicing impossible. Blocking the function of the spliceosome may be an important pathway for BPA affecting testicular development. In conclusion, the current study results revealed that exposure to low dose BPA (at NAOEF or even at TDI) adversely affected testicular development by inhibiting SCP3 protein expression and down-regulation of Snrpc and Hnrnpu expressions in the testis.

\section{Conclusions}

The current study investigated the effects of BPA exposure at $0.05,0.5,5,10,20,50 \mathrm{mg} / \mathrm{kg} / \mathrm{d}$ on the development of testes in male mice offspring. The results showed that exposure to BPA significantly increased BPA contents in testis at BPA $\geq 20 \mathrm{mg} / \mathrm{kg} / \mathrm{d}$ and serum at BPA $\geq 10 \mathrm{mg} / \mathrm{kg} / \mathrm{d}$ of PND $45 \mathrm{mice}$. BPA exposure at $0.05 \mathrm{mg} / \mathrm{kg} / \mathrm{d}$ (TDI) caused damages in spermatogenic cells and seminiferous tubules. 
Subject to BPA at a low dose $(0.05 \mathrm{mg} / \mathrm{kg} / \mathrm{d})$ significantly reduced the expression of Scp3 proteins and elevated sperm abnormality, suggesting BPA inhibits the transformation of spermatogonia into spermatozoa in the testis. Sperm cells became apoptotic when BPA dosages were at $\geq 0.5 \mathrm{mg} / \mathrm{kg} / \mathrm{d}$. BPA exposure significantly inhibited spliceosome and significantly reduced the expression of Snrpc (BPA $\geq 20$ $\mathrm{mg} / \mathrm{kg} / \mathrm{d}$ ) and Hnrnpu (BPA $\geq 0.5 \mathrm{mg} / \mathrm{kg} / \mathrm{d}$ ). This study has fully demonstrated that low-dose long-term exposure to BPA inhibits spermatogonial meiosis and impairs the reproductive function of testis in male mice.

\section{Materials And Methods}

\section{Reagent and Animal treatments}

BPA stock solution at $50 \mathrm{mg} / \mathrm{ml}$ was prepared using solid BPA (purity $\geq 99 \%$, Sigma, US), and stored at $4^{\circ} \mathrm{C}$. When used, the stock solution was fixed to the desired concentration with distilled water containing $0.5 \mathrm{~mol} / \mathrm{L} \mathrm{NAOH}$ and $25 \%$ ethanol.

The experiments were conducted with 8-week-old Kunming mice weighing $20 \pm 2 \mathrm{~g}$, supplied by the Beijing Sibefu Experimental Animal Center (ID number: SCXK, Beijing 2016-0002). Two females were caged overnight, with one male after one week of acclimatization. Confirmation of a vaginal plug in the following morning was designated as gestation day 0 (GD 0). Pregnant mice were then randomly divided into 7 groups of 20 mice each and given different doses of BPA by drinking water from GD 0 to the end of the lactation period. Group A was the control group in which the mice received BPA at $0.00 \mathrm{mg} / \mathrm{kg} / \mathrm{d}$; Mice in groups B-G were treated with BPA at $0.05,0.5,5,10,20,50 \mathrm{mg} / \mathrm{kg} / \mathrm{d}$ in drinking water, respectively. After weaning at postnatal day 21 (PND 21), the F1 male mice continued to drink BPA at the same dosages as their mothers until day 45 (PND 45). The total BPA exposure duration was 63 days. To ensure the accurate intake amount of BPA solution, water daily intake by each group of mice was accurately measured. The concentration of BPA solution was adjusted accordingly, as described by Zhang and his colleagues (2019). Animal using procedures were approved by the Animal Welfare Committee of the Agricultural University of Hebei, China (approval No. IACECHEBAU20171017).

\section{Measurement of BPA contents in serum and testicular tissues}

BPA levels in serum and testes homogenates of the F1 mice were detected using the BPA assay kit (Shanghai Runyu Biotechnology Co., Ltd., Lot No: RY-12919) following the manufacturer's instructions. Briefly, serum or testicular homogenate of $50 \mu \mathrm{l}$ was added to the ELISA plate in duplicates and incubated at $37^{\circ} \mathrm{C}$ for $30 \mathrm{~min}$. Then $50 \mu \mathrm{l}$ enzyme-labeled reagents were added after washing and incubated at 37 ${ }^{\circ} \mathrm{C}$ for $30 \mathrm{~min}$. The optical density (OD) values were read at $450 \mathrm{~nm}$ using a plate reader (H4MFPTAD, BioTek). 


\section{H\&E staining of testes}

Testes samples were fixed with $4 \%$ paraformaldehyde and embedded in paraffin. $5 \mu \mathrm{m}$ thickness was prepared and stained with hematoxylin-eosin (H\&E) to observe histopathological damages and immunohistochemistry.

\section{Immunohistochemistry for synaptonemal complex protein 3 (Scp3) in testes}

The paraffin sections of testicular samples were xylene-dewaxed and rehydrated with graded ethanol. The sections were then incubated with $3 \% \mathrm{H}_{2} \mathrm{O}_{2}$ at $37^{\circ} \mathrm{C}$ for 10 min to quench the endogenous peroxidase. After washing with phosphate-buffered saline (PBS) three times, the slides were incubated with bovine serum albumin (BSA,5\%) at $37^{\circ} \mathrm{C}$ for $10 \mathrm{~min}$ to reduce the non-specific staining. After that, the sections were covered with rabbit anti-mouse SCP-3 antibody (bs-3509R, Bioss, China) and incubated overnight at $4{ }^{\circ} \mathrm{C}$. The sections were then incubated with goat anti-rabbit antibody (bs-0259G-Bio, Bioss, China) at $37^{\circ} \mathrm{C}$ for $30 \mathrm{~min}$. The sections were covered with horseradish peroxidase-labeled streptavidin (bs-0437P-HRP, Bioss, China) at $37^{\circ} \mathrm{C}$ for 30 min after being washed three times with PBS. Finally, the sections were washed with PBS and then visualized with 3,3'-diaminobenzidine (DAB; CWBIO). The positive cells were stained in brown color. The negative controls were processed in the same procedure except that the primary antibody was replaced with PBS.

\section{Sperm apoptosis in testes}

Testes were chopped and mixed with RMPI 1640 medium $\left(37^{\circ} \mathrm{C}\right)$, then pipette $10 \mu \mathrm{l}$ of the sample and mixed it with $120 \mu$ l low melting point agarose $\left(0.5 \%, 37^{\circ} \mathrm{C}\right)$. Then, the mixture was transferred to the glass slide and let to solidify. The finished slides were placed in lysate solution for digestion $\left(4^{\circ} \mathrm{C}, 1 \mathrm{~h}\right.$; Lysate solution: $2.5 \mathrm{~mol} / \mathrm{L} \mathrm{NaCl}, 100 \mathrm{mmol} / \mathrm{L} \mathrm{MTA}, 10 \mathrm{mmol} / \mathrm{L}$ Tris, aqueous solution, $\mathrm{pH} 10.0,89 \mathrm{ml}$; Triton X- Mix $1001 \mathrm{ml}$ and DMSO $10 \mathrm{ml})$. After that, electrophoresis $\left(4^{\circ} \mathrm{C}, 1.2 \mathrm{~V} / \mathrm{cm}, 300 \mathrm{~mA}, 20 \mathrm{~min}\right)$ was performed. Finally, the slides were stained with ethidium bromide $(20 \mu \mathrm{g} / \mathrm{ml})$ and observed using fluorescence microscopic imaging system (Olympus BX43, US). The tail formed by DNA fragments represents the degree of DNA damage. The damage was calculated by the Olive Tail Moment (OTM) value, which is the percentage of tail DNA multiplied by the distance between the tail and the head.

\section{Sperm count and abnormality}

The cauda epididymis of mice was collected and macerated in $1 \mathrm{~mL}$ of phosphate-buffered saline. The obtained suspension was filtered to remove tissue debris. Sperm count was conducted under a light microscope using a haemocytometer [42]. In measuring sperm abnormality, the separated cauda epididymis was placed in $1 \mathrm{ml}$ phosphate-buffered saline and minced to obtain the suspension as 
mentioned above. Then the suspension was filtered through a fine mesh cloth to remove tissue debris. After the staining with $1 \%$ eosin $Y$ for 20 minutes, a suspension drop was transferred onto a clean slide and air-dried. One thousand sperms per animal were scored from each group for the presence of sperm shape abnormalities [43].

\section{RNA sequencing}

Total RNA from the testicular tissues was extracted using Eastep Super Total RNA Extraction Kit (LS1040, Promega, USA). Then it was reversed using the Advantage RT-for-PCR Kit (Code No. 639505, TAKARA, Japan) for the CDNA synthesis. The testis of the BPA $50 \mathrm{mg} / \mathrm{kg} / \mathrm{d}$ group and the control group were subjected to transcriptome sequencing using the Illumina HiSeq Illumina sequencing platform. The GO categories and KEGG pathways were clustered using the DAVID Functional Annotation Clustering tool [44].

\section{RT-qPCR for splicesome}

All 7 groups of differentially expressed genes in the splicing were verified by RT QPCR, and the primer sequences are listed below (Table 1). RT qPCR method: RT qPCR mixture10 $\mu$; forward primer $1 \mu \mathrm{l}$; reverse primer $1 \mu \mathrm{l} ; \mathrm{cDNA}$ of samples $2 \mu \mathrm{l} ; \mathrm{ddH}_{2} \mathrm{O} 6 \mu \mathrm{l}$. Amplification procedure: $95^{\circ} \mathrm{C}$ for $600 \mathrm{~s} ; 95^{\circ} \mathrm{C}$ for $30 \mathrm{~s}, 60^{\circ} \mathrm{C}$ for $10 \mathrm{~s}, 45$ cycles. Melting curve program: $95^{\circ} \mathrm{C}$ for $10 \mathrm{~s}, 65^{\circ} \mathrm{C}$ for $60 \mathrm{~s}$ and then ramped to $97^{\circ} \mathrm{C}$ at a rate of $0.2^{\circ} \mathrm{C} / \mathrm{s}$, and finally cooled at $37^{\circ} \mathrm{C}$ for $30 \mathrm{~s}$.

\section{Statistical Analysis}

Immunohistochemistry results were analyzed using Image $\mathrm{J}$, and the results of the comet assay were detected using the comet assay software project (CASP) software. The test data were analyzed with SPSS 19.0 software, and the results were expressed as mean \pm standard error ( $x \pm$ SEM). Data were analyzed by one-way ANOVA and Chi-square test $\left(X^{2}\right), P<0.05$ indicates significant difference.

\section{Declarations}

\section{Availability of data and material}

The data of this study are available on request from the corresponding authors.

\section{Acknowledgements}

Not applicable. 


\section{Funding}

This study was financially supported by the National Natural Science Foundation of China (No.30972208), and the Start-up Project of High-Level Talents Scientific Research in Shihezi University (No. KX015201).

\section{Contributions}

Yongjie Wang and Shilei Zhang wrote the main manuscript text. Shilei Zhang contributed to the design, sample collection, and experimental procedures of the study. Yanyan Wu prepared tables and figures. All authors reviewed the manuscript.

\section{Ethics declarations}

\section{Ethics approval and consent to participate}

All experimental designs and methods were performed in accordance with the relevant guidelines and regulations (Animal Ethics Procedures and Guidelines of the Ministry of Agriculture of China), and also approved by the Animal Welfare Committee of the Agricultural University of Hebei, China (approval No. IACECHEBAU20171017). All efforts were made to minimize animal suffering during sample collection.

\section{Conflicts of interest (COI)}

The authors declare that there are no conflicts of interest regarding the publication of this paper.

\section{References}

1. Rani M, Shim WJ, Han GM, Jang M, Al-Odaini NA, Song YK, Hong SHJAoec, toxicology: Qualitative analysis of additives in plastic marine debris and its new products. 2015, 69(3):352-366.

2. Jandegian CM, Deem SL, Bhandari RK, Holliday CM, Nicks D, Rosenfeld CS, Selcer KW, Tillitt DE, Vom Saal FS, Vélez-Rivera VJG et al: Developmental exposure to bisphenol A (BPA) alters sexual differentiation in painted turtles (Chrysemys picta). 2015, 216:77-85.

3. Zhu Q, Jia J, Zhang K, Zhang H, Liao CJSotte: Spatial distribution and mass loading of phthalate esters in wastewater treatment plants in China: An assessment of human exposure. 2019, 656:862869.

4. Srivastava S, Gupta P, Chandolia A, Alam IJJoEH: SPECIAL REPORT: Bisphenol A: A Threat to Human Health? 2015, 77(6):20-27. 
5. Ohtani N, Suda K, Tsuji E, Tanemura K, Yokota H, Inoue H, Iwano HJJoVMS: Late pregnancy is vulnerable period for exposure to BPA. 2018:17-0460.

6. Yu M, Xu Y, Li M, Li D, Lu Y, Yu D, Du WJG, endocrinology c: Bisphenol A accelerates meiotic progression in embryonic chickens via the estrogen receptor $\beta$ signaling pathway. 2018, 259:66-75.

7. Zhu X, Tian GG, Yu B, Yang Y, Wu JJAot: Effects of bisphenol A on ovarian follicular development and female germline stem cells. 2018, 92(4):1581-1591.

8. Yamamoto T, Yasuhara A, Shiraishi $\mathrm{H}$, Nakasugi OJC: Bisphenol A in hazardous waste landfill leachates. 2001, 42(4):415-418.

9. Belfroid $A$, van Velzen $M$, van der Horst B, Vethaak DJC: Occurrence of bisphenol A in surface water and uptake in fish: evaluation of field measurements. 2002, 49(1):97-103.

10. Petrie B, Lopardo L, Proctor K, Youdan J, Barden R, Kasprzyk-Hordern BJSotte: Assessment of bisphenol-A in the urban water cycle. 2019, 650:900-907.

11. Santos JM, Putt DA, Jurban M, Joiakim A, Friedrich K, Kim HJEm, assessment: Differential BPA levels in sewage wastewater effluents from metro Detroit communities. 2016, 188(10):1-6.

12. Santonicola S, Ferrante MC, di Leo G, Murru N, Anastasio A, Mercogliano RJljofs: Study on endocrine disruptors levels in raw milk from cow's farms: Risk assessment. 2018, 7(3).

13. Alnaimat AS, Barciela-Alonso MC, Bermejo-Barrera PJMJ: Determination of bisphenol A in tea samples by solid phase extraction and liquid chromatography coupled to mass spectrometry. 2019, 147:598-604.

14. Cooper JE, Kendig EL, Belcher SMJC: Assessment of bisphenol A released from reusable plastic, aluminium and stainless steel water bottles. 2011, 85(6):943-947.

15. Cao X-L, Corriveau J, Popovic SJJofp: Sources of low concentrations of bisphenol A in canned beverage products. 2010, 73(8):1548-1551.

16. Ji H, Miao M, Liang H, Shi H, Ruan D, Li Y, Wang J, Yuan WJSr: Exposure of environmental Bisphenol $A$ in relation to routine sperm parameters and sperm movement characteristics among fertile men. 2018, 8(1):1-9.

17. Rahman MS, Kwon W-S, Karmakar PC, Yoon S-J, Ryu B-Y, Pang M-GJEhp: Gestational exposure to bisphenol A affects the function and proteome profile of F1 spermatozoa in adult mice. 2017, 125(2):238-245.

18. van Woerden I, Bruening M, Montresor-López J, Payne-Sturges DCJEr: Trends and disparities in urinary BPA concentrations among US emerging adults. 2019, 176:108515.

19. Dalkan C, Uncu M, Duran S, Bahçeciler NNJTJoM-F, Medicine N: Association of cord blood bisphenol A (BPA) with cord blood adiponectin, leptin, fetal growth; adiposity and neoantal complications in a newborn cohort. 2020, 33(15):2588-2593.

20. Liao C, Kannan KJEs, technology: Determination of free and conjugated forms of bisphenol A in human urine and serum by liquid chromatography-tandem mass spectrometry. 2012, 46(9):50035009. 
21. Deng W-J, Li N, Wu R, Richard WK, Wang Z, Ho WJEP: Phosphorus flame retardants and Bisphenol A in indoor dust and PM2. 5 in kindergartens and primary schools in Hong Kong. 2018, 235:365-371.

22. Geens T, Roosens L, Neels H, Covaci AJC: Assessment of human exposure to Bisphenol-A, Triclosan and Tetrabromobisphenol-A through indoor dust intake in Belgium. 2009, 76(6):755-760.

23. Graziani NS, Carreras H, Wannaz EJH: Atmospheric levels of BPA associated with particulate matter in an urban environment. 2019, 5(4):e01419.

24. Campos PD, Oliveira IM, Sena de Souza J, Da Conceição RR, Giannocco G, Chiamolera MI, Silva MRD-D, Romano MA, Romano RMJJoT, Environmental Health PA: Maternal bisphenol A exposure disrupts spermatogenesis in adult rat offspring. 2019, 82(3):163-175.

25. Dobrzyńska MM, Radzikowska JJD, toxicology c: Genotoxicity and reproductive toxicity of bisphenol A and X-ray/bisphenol A combination in male mice. 2013, 36(1):19-26.

26. Wang YQ, Li YW, Chen QL, Liu ZHJEP: Long-term exposure of xenoestrogens with environmental relevant concentrations disrupted spermatogenesis of zebrafish through altering sex hormone balance, stimulating germ cell proliferation, meiosis and enhancing apoptosis. 2019, 244:486-494.

27. Jones RL, Lang SA, Kendziorski JA, Greene AD, Burns KAJEhp: Use of a mouse model of experimentally induced endometriosis to evaluate and compare the effects of bisphenol $A$ and bisphenol AF exposure. 2018, 126(12):127004.

28. Chianese R, Viggiano A, Urbanek K, Cappetta D, Troisi J, Scafuro M, Guida M, Esposito G, Ciuffreda LP, Rossi FJSr: Chronic exposure to low dose of bisphenol A impacts on the first round of spermatogenesis via SIRT1 modulation. 2018, 8(1):1-12.

29. Yue M, Fan X, Liu Y, Yue W, Ren G, Zhang J, Zhang X, Li Q, He JJAh: Effects of body temperature on the expression and localization of meiosis-related proteins STRA8 and SCP3 in boar testes. 2019, 121(6):718-723.

30. Yuan L, Liu J-G, Hoja M-R, Wilbertz J, Nordqvist K, Höög CJS: Female germ cell aneuploidy and embryo death in mice lacking the meiosis-specific protein SCP3. 2002, 296(5570):1115-1118.

31. Aarabi M, Modarressi MH, Soltanghoraee H, Behjati R, Amirjannati N, Akhondi MMJF, sterility: Testicular expression of synaptonemal complex protein 3 (SYCP3) messenger ribonucleic acid in 110 patients with nonobstructive azoospermia. 2006, 86(2):325-331.

32. Costa V, Aprile M, Esposito R, Ciccodicola AJEJoHG: RNA-Seq and human complex diseases: recent accomplishments and future perspectives. 2013, 21(2):134-142.

33. Marguerat S, Bähler JJC, sciences ml: RNA-seq: from technology to biology. 2010, 67(4):569-579.

34. Siracusa JS, Yin L, Measel E, Liang S, Yu XJRt: Effects of bisphenol A and its analogs on reproductive health: A mini review. 2018, 79:96-123.

35. Ma S, Li R, Gong X, Shi W, Zhong XJES, Research P: Lycopene reduces in utero bisphenol A exposureinduced mortality, benefits hormones, and development of reproductive organs in offspring mice. 2018, 25(24):24041-24051. 
36. Mita L, Baldi A, Diano N, Viggiano E, Portaccio M, Nicolucci C, Grumiro L, Menale C, Mita D, Spugnini EJEt et al: Differential accumulation of BPA in some tissues of offspring of Balb-C mice exposed to different BPA doses. 2012, 33(1):9-15.

37. Jean-Faucher $C$, Berger $M$, de Turckheim $M$, Veyssière $G$, Jean CJN: The effect of preweaning undernutrition upon the sexual development of male mice. 1982, 41(1-2):45-51.

38. Yuan L, Liu J-G, Zhao J, Brundell E, Daneholt B, Höög CJMc: The murine SCP3 gene is required for synaptonemal complex assembly, chromosome synapsis, and male fertility. 2000, 5(1):73-83.

39. Guo Z, Karunatilaka KS, Rueda DJNs, biology m: Single-molecule analysis of protein-free U2-U6 snRNAs. 2009, 16(11):1154-1159.

40. Sharma S, Wongpalee SP, Vashisht A, Wohlschlegel JA, Black DLJG, development: Stem-loop 4 of U1 snRNA is essential for splicing and interacts with the U2 snRNP-specific SF3A1 protein during spliceosome assembly. 2014, 28(22):2518-2531.

41. Liu W, Wang F, Xu Q, Shi J, Zhang X, Lu X, Zhao Z-A, Gao Z, Ma H, Duan EJNc: BCAS2 is involved in alternative mRNA splicing in spermatogonia and the transition to meiosis. 2017, 8(1):1-11.

42. Kowalczuk C, Saunders R, Stapleton HJMRL: Sperm count and sperm abnormality in male mice after exposure to $2.45 \mathrm{GHz}$ microwave radiation. 1983, 122(2):155-161.

43. Alabi OA, Esan BE, Sorungbe AAJJoH, Pollution: Genetic, reproductive and hematological toxicity induced in mice exposed to leachates from petrol, diesel and kerosene dispensing sites. 2017, 7(16):58-70.

44. Dennis G, Sherman BT, Hosack DA, Yang J, Gao W, Lane HC, Lempicki RAJGb: DAVID: database for annotation, visualization, and integrated discovery. 2003, 4(9):1-11.

\section{Tables}

Table 1

Real-time PCR primer sequences

\begin{tabular}{|c|c|c|c|c|c|}
\hline Gene ID & & Sequence(5'-3') & GC\% & $\mathrm{Tm}$ & length(bp) \\
\hline \multirow[t]{2}{*}{ Snrpc } & $\mathrm{F}$ & AACGGCTTGTGGAGCATCA & 52.6 & 62.8 & \multirow[t]{2}{*}{177} \\
\hline & $\mathrm{R}$ & TGTCTTGTCAATCAGGCTCTGG & 50 & 62.7 & \\
\hline \multirow[t]{2}{*}{ Hnrnpu } & $\mathrm{F}$ & TGCCCAACAGAGGGAACTATAACC & 50 & 64.5 & \multirow[t]{2}{*}{142} \\
\hline & $\mathrm{R}$ & CCTTGGTGATAATGCTGACTCCA & 47.8 & 63.5 & \\
\hline \multirow[t]{2}{*}{$\beta$-actin } & $\mathrm{F}$ & TCCTTCCTGGGCATGGAGT & 57.9 & 63 & \multirow[t]{2}{*}{104} \\
\hline & $\mathrm{R}$ & AGCACTGTGTTGGCGTACAG & 55 & 60 & \\
\hline
\end{tabular}


Table 2

BPA content in serum and testis

\begin{tabular}{|lll|}
\hline Groups $(\mathrm{n}=5)$ & Serum $(\mathrm{ng} / \mathrm{mL})$ & Testis $(\mathrm{ng} / \mathrm{g})$ \\
\hline Control group & $1.19 \pm 0.10^{\mathrm{a}}$ & $1.23 \pm 0.12^{\mathrm{a}}$ \\
\hline BPA $0.05 \mathrm{mg} / \mathrm{kg} / \mathrm{d}$ & $1.20 \pm 0.08^{\mathrm{a}}$ & $1.30 \pm 0.09^{\mathrm{a}}$ \\
\hline BPA $0.5 \mathrm{mg} / \mathrm{kg} / \mathrm{d}$ & $1.37 \pm 0.08^{\mathrm{ab}}$ & $1.35 \pm 0.14^{\mathrm{a}}$ \\
\hline BPA $5 \mathrm{mg} / \mathrm{kg} / \mathrm{d}$ & $1.46 \pm 0.11^{\mathrm{ab}}$ & $1.48 \pm 0.13^{\mathrm{a}}$ \\
\hline BPA $10 \mathrm{mg} / \mathrm{kg} / \mathrm{d}$ & $1.64 \pm 0.16^{\mathrm{b}}$ & $1.60 \pm 0.12^{\mathrm{a}}$ \\
\hline BPA $20 \mathrm{mg} / \mathrm{kg} / \mathrm{d}$ & $2.18 \pm 0.13^{\mathrm{c}}$ & $2.17 \pm 0.12^{\mathrm{b}}$ \\
\hline BPA $50 \mathrm{mg} / \mathrm{kg} / \mathrm{d}$ & $2.72 \pm 0.12^{\mathrm{d}}$ & $2.67 \pm 0.20^{\mathrm{c}}$ \\
\hline
\end{tabular}

Note: Different lowercase letters in each column indicate significant differences $(P<0.05)$.

\section{Table 3}

\section{Seminiferous tubule cavities and epithelial height of testis}

\begin{tabular}{|lll|}
\hline Groups $(\mathrm{n}=13)$ & Lumen diameter $(\mu \mathrm{m})$ & Epithelial height $(\mu \mathrm{m})$ \\
\hline Control group & $37.26 \pm 5.32^{\mathrm{a}}$ & $52.39 \pm 2.83^{\mathrm{e}}$ \\
\hline BPA $0.05 \mathrm{mg} / \mathrm{kg} / \mathrm{d}$ & $50.23 \pm 3.54^{\mathrm{b}}$ & $48.41 \pm 2.95^{\mathrm{de}}$ \\
\hline BPA $0.5 \mathrm{mg} / \mathrm{kg} / \mathrm{d}$ & $62.58 \pm 3.10^{\mathrm{cd}}$ & $37.03 \pm 2.10^{\mathrm{abc}}$ \\
\hline BPA $5 \mathrm{mg} / \mathrm{kg} / \mathrm{d}$ & $69.41 \pm 2.62^{\mathrm{d}}$ & $41.37 \pm 1.60^{\mathrm{bc}}$ \\
\hline BPA $10 \mathrm{mg} / \mathrm{kg} / \mathrm{d}$ & $62.69 \pm 3.65^{\mathrm{cd}}$ & $42.90 \pm 2.58^{\mathrm{cd}}$ \\
\hline BPA $20 \mathrm{mg} / \mathrm{kg} / \mathrm{d}$ & $54.64 \pm 4.28^{\mathrm{bc}}$ & $34.10 \pm 1.47^{\mathrm{a}}$ \\
\hline BPA $50 \mathrm{mg} / \mathrm{kg} / \mathrm{d}$ & $64.28 \pm 1.90^{\mathrm{cd}}$ & $35.01 \pm 1.57^{\mathrm{ab}}$ \\
\hline
\end{tabular}

Note: "Lumen diameter" is the diameter of the hollow space in the seminiferous tubules of the testicular HE stained image measured by Image $J$ software; and "Epithelial height" is the thickness of the seminiferous tubules. Results are expressed as mean \pm standard error. Different lowercase letters in each column indicate significant differences $(P<0.05)$. 


\section{Table 4}

\section{Scp3 expressions in spermatogenic cells of different BPA exposure groups}

\begin{tabular}{|ll|}
\hline Groups $(\mathrm{n}=3)$ & $\mathrm{Scp} 3$ \\
\hline Control group & $59.75 \pm 0.56^{\mathrm{c}}$ \\
\hline BPA $0.05 \mathrm{mg} / \mathrm{kg} / \mathrm{d}$ & $49.11 \pm 2.42^{\mathrm{b}}$ \\
\hline BPA $0.5 \mathrm{mg} / \mathrm{kg} / \mathrm{d}$ & $47.74 \pm 3.77^{\mathrm{b}}$ \\
\hline BPA $5 \mathrm{mg} / \mathrm{kg} / \mathrm{d}$ & $43.21 \pm 2.63^{\mathrm{ab}}$ \\
\hline BPA $10 \mathrm{mg} / \mathrm{kg} / \mathrm{d}$ & $44.34 \pm 0.72^{\mathrm{b}}$ \\
\hline BPA $20 \mathrm{mg} / \mathrm{kg} / \mathrm{d}$ & $36.38 \pm 1.29^{\mathrm{a}}$ \\
\hline BPA $50 \mathrm{mg} / \mathrm{kg} / \mathrm{d}$ & $35.89 \pm 3.18^{\mathrm{a}}$ \\
\hline
\end{tabular}

Note: The data is the average gray value of positive staining in the testis Scp 3 immunohistochemical results measured by Image $\mathrm{J}$ software, and the results are expressed as the mean \pm standard error. Different lowercase letters indicate significant difference $(P<0.05)$.

\section{Table 5}

\section{DNA damages in Testicular germ cells}

\begin{tabular}{|ll|}
\hline Group $(\mathrm{n}=11)$ & OTM value \\
\hline Control group & $0.14 \pm 0.06^{\mathrm{a}}$ \\
\hline BPA $0.05 \mathrm{mg} / \mathrm{kg} / \mathrm{d}$ & $10.13 \pm 1.43^{\mathrm{ab}}$ \\
\hline BPA $0.5 \mathrm{mg} / \mathrm{kg} / \mathrm{d}$ & $18.10 \pm 2.03^{\mathrm{b}}$ \\
\hline BPA $5 \mathrm{mg} / \mathrm{kg} / \mathrm{d}$ & $18.81 \pm 1.75^{\mathrm{bc}}$ \\
\hline BPA $10 \mathrm{mg} / \mathrm{kg} / \mathrm{d}$ & $29.11 \pm 2.76^{\mathrm{c}}$ \\
\hline BPA $20 \mathrm{mg} / \mathrm{kg} / \mathrm{d}$ & $50.17 \pm 6.79^{\mathrm{d}}$ \\
\hline BPA $50 \mathrm{mg} / \mathrm{kg} / \mathrm{d}$ & $66.21 \pm 5.68^{\mathrm{e}}$ \\
\hline
\end{tabular}

Note: OTM is the percentage of total DNA in the tail DNA multiplied by the center of gravity of the tail DNA and the distance of the DNA of the comet head in the $x$-axis. There was a significant difference between 
the groups of different BPA doses indicated by lowercase letters $(P<0.05)$.

\section{Table 6}

\section{Sperm count and abnormality rate of mice}

\begin{tabular}{|llll|}
\hline Group $(\mathrm{n}=5)$ & Sperm count (ANOVA) & Abnormality rate $\left(\chi^{2}\right)$ & Abnormality rate $P$-value \\
\hline Control group & $626.00 \pm 59.91^{\mathrm{c}}$ & 0.14 & \\
\hline BPA $0.05 \mathrm{mg} / \mathrm{kg} / \mathrm{d}$ & $628.33 \pm 20.20^{\mathrm{c}}$ & 0.21 & $1.81 \mathrm{E}-05$ \\
\hline BPA $0.5 \mathrm{mg} / \mathrm{kg} / \mathrm{d}$ & $490.00 \pm 24.79^{\mathrm{b}}$ & 0.24 & $1.21 \mathrm{E}-08$ \\
\hline BPA $5 \mathrm{mg} / \mathrm{kg} / \mathrm{d}$ & $420.33 \pm 55.11^{\mathrm{b}}$ & 0.33 & $5.63 \mathrm{E}-27$ \\
\hline BPA $10 \mathrm{mg} / \mathrm{kg} / \mathrm{d}$ & $215.67 \pm 12.45^{\mathrm{a}}$ & 0.40 & $2.68 \mathrm{E}-34$ \\
\hline BPA $20 \mathrm{mg} / \mathrm{kg} / \mathrm{d}$ & $198.33 \pm 19.22^{\mathrm{a}}$ & 0.41 & $3.29 \mathrm{E}-33$ \\
\hline BPA $50 \mathrm{mg} / \mathrm{kg} / \mathrm{d}$ & $183.33 \pm 6.57^{\mathrm{a}}$ & 0.63 & $1.57 \mathrm{E}-104$ \\
\hline
\end{tabular}

sperm count is the number of sperm in the whole field of microscope at 200X magnification after the sperm smear is finished. Different lowercase letters or $P \otimes 0.05$ means significant difference. The results are expressed as the mean \pm standard error.

\section{Figures}
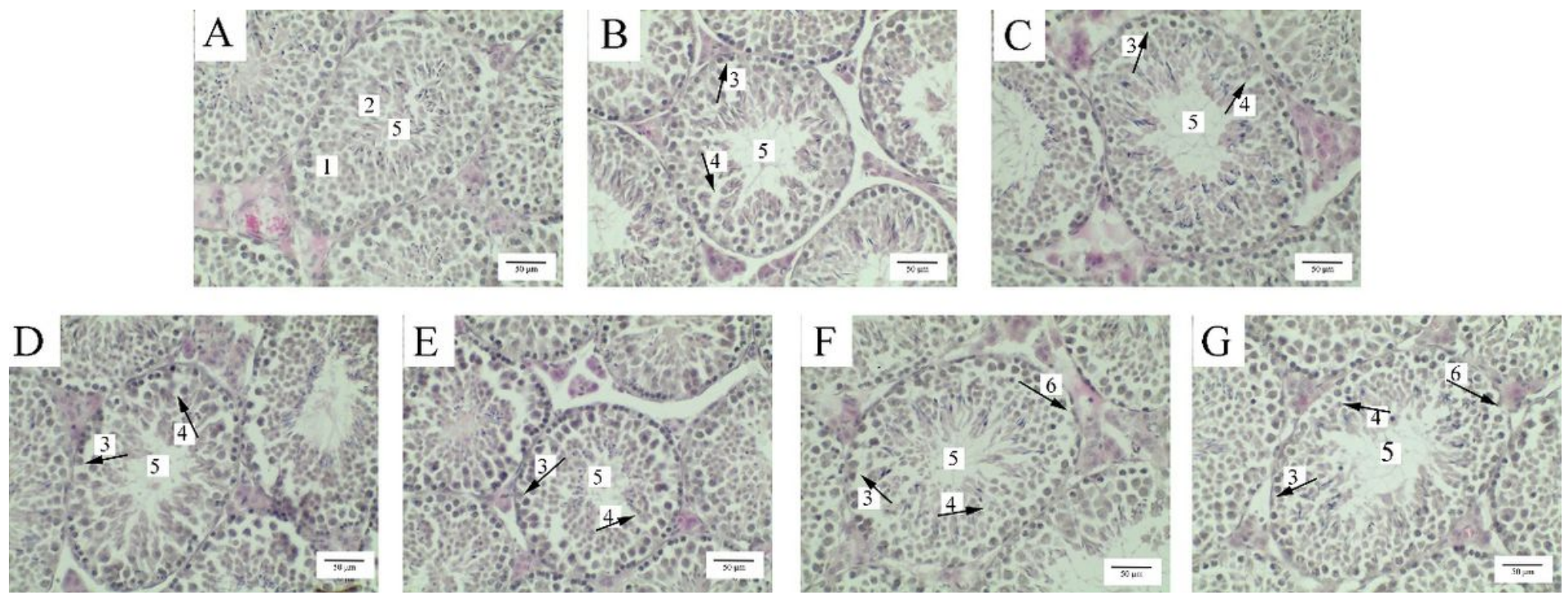

Figure 1 
Testicular histopathological changes Note: (A) the Control group; showing normal morphology of closely packed seminiferous tubules. (B) BPA $0.05 \mathrm{mg} / \mathrm{kg} / \mathrm{d}$ group; (C) BPA $0.5 \mathrm{mg} / \mathrm{kg} / \mathrm{d}$ group; (D) BPA 5 $\mathrm{mg} / \mathrm{kg} / \mathrm{d}$ group; (E) BPA $10 \mathrm{mg} / \mathrm{kg} / \mathrm{d}$ group; (F) BPA $20 \mathrm{mg} / \mathrm{kg} / \mathrm{d}$ group; (G) BPA $50 \mathrm{mg} / \mathrm{kg} / \mathrm{d}$ group. 1, indicates the basal lamina; 2 , the spermatogonia; 3 , spaces between the basal lamina and the spermatogonia ; 4, abnormal spaces in-between spermatogenic epithelium spermatogonia; 5, Lumen; 6 , incomplete basal lamina. $\mathrm{n}=3$
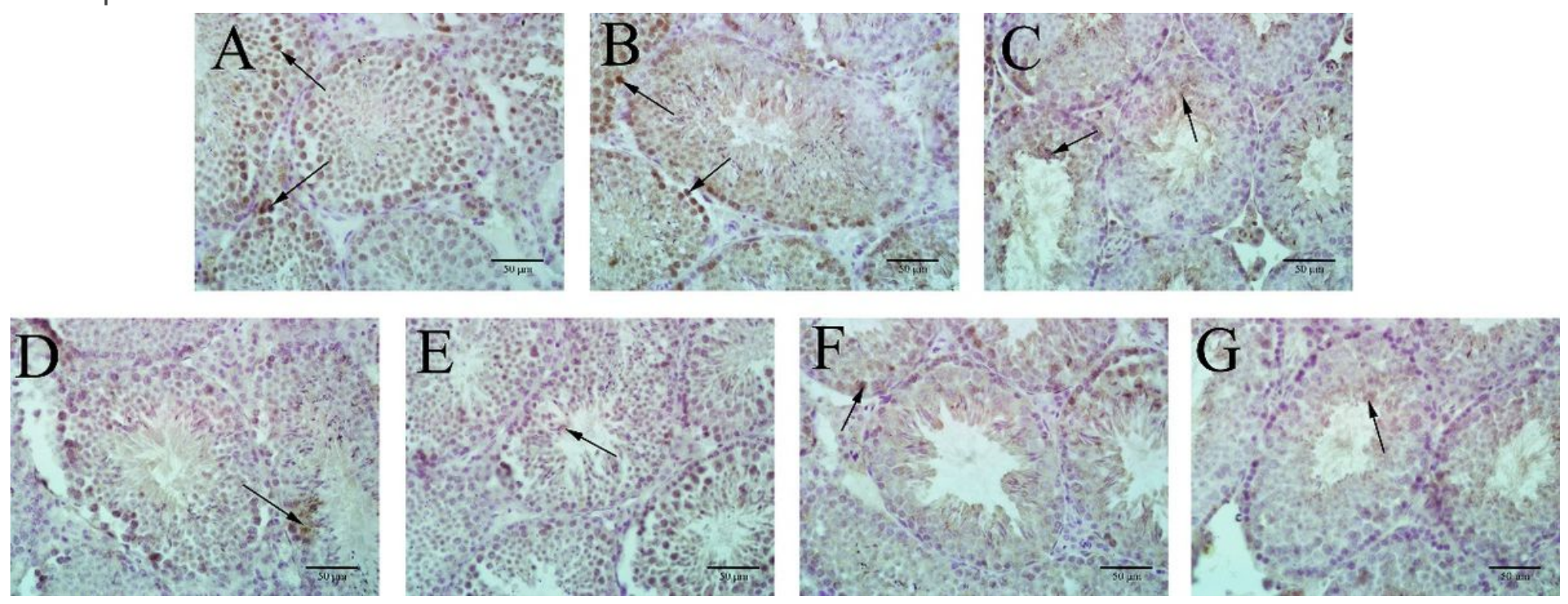

Figure 2

Scp3 expression in spermatogenic cells of different BPA groups Note: Groups A was the control group. Groups B-G were $0.05,0.5,5,10,20,50 \mathrm{mg} / \mathrm{kg} / \mathrm{d}$ BPA groups. The arrows indicate positive staining of Scp3 protein. $\mathrm{n}=3$
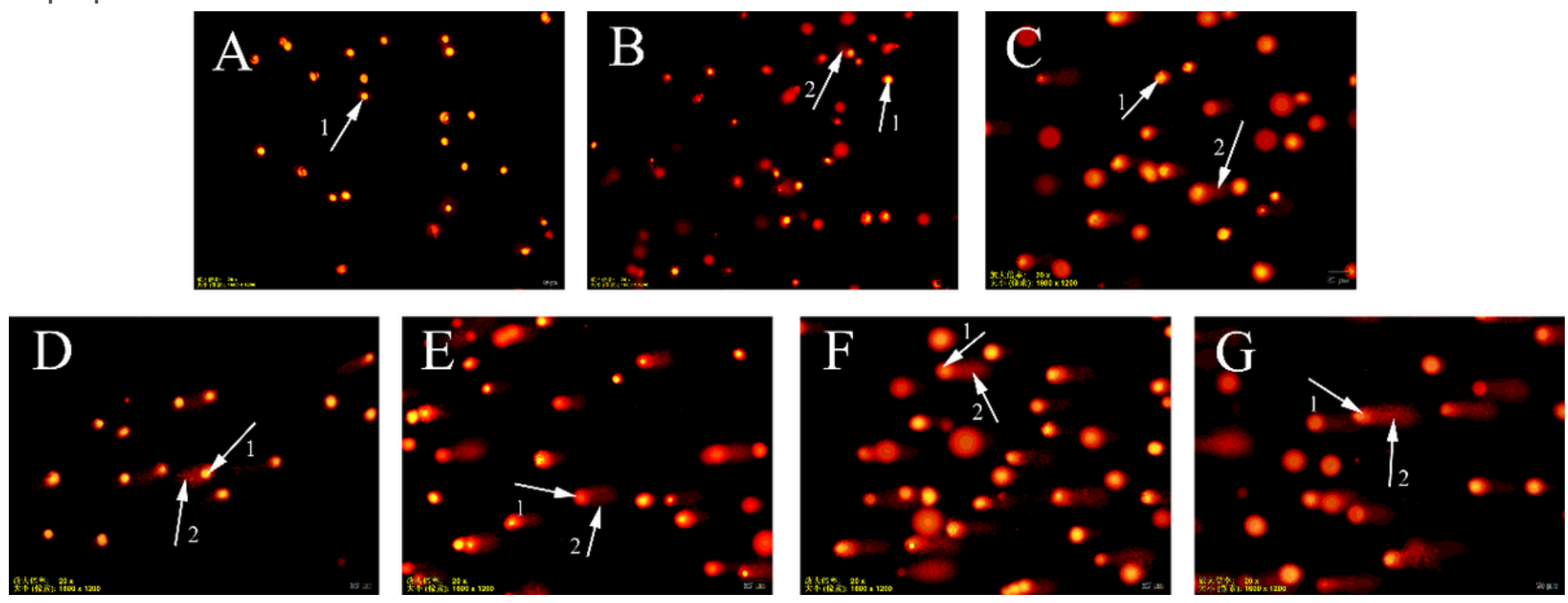

Figure 3

Effect of BPA on mice spermatogonia DNA damage Note: Group A was the control group, groups B-G were $0.05,0.5,5,10,20,50 \mathrm{mg} / \mathrm{kg} / \mathrm{d}$ BPA groups, respectively. Arrow 1 refers to the nucleus, and arrow 2 
refers to the DNA fragments produced by apoptosis. $n=11$
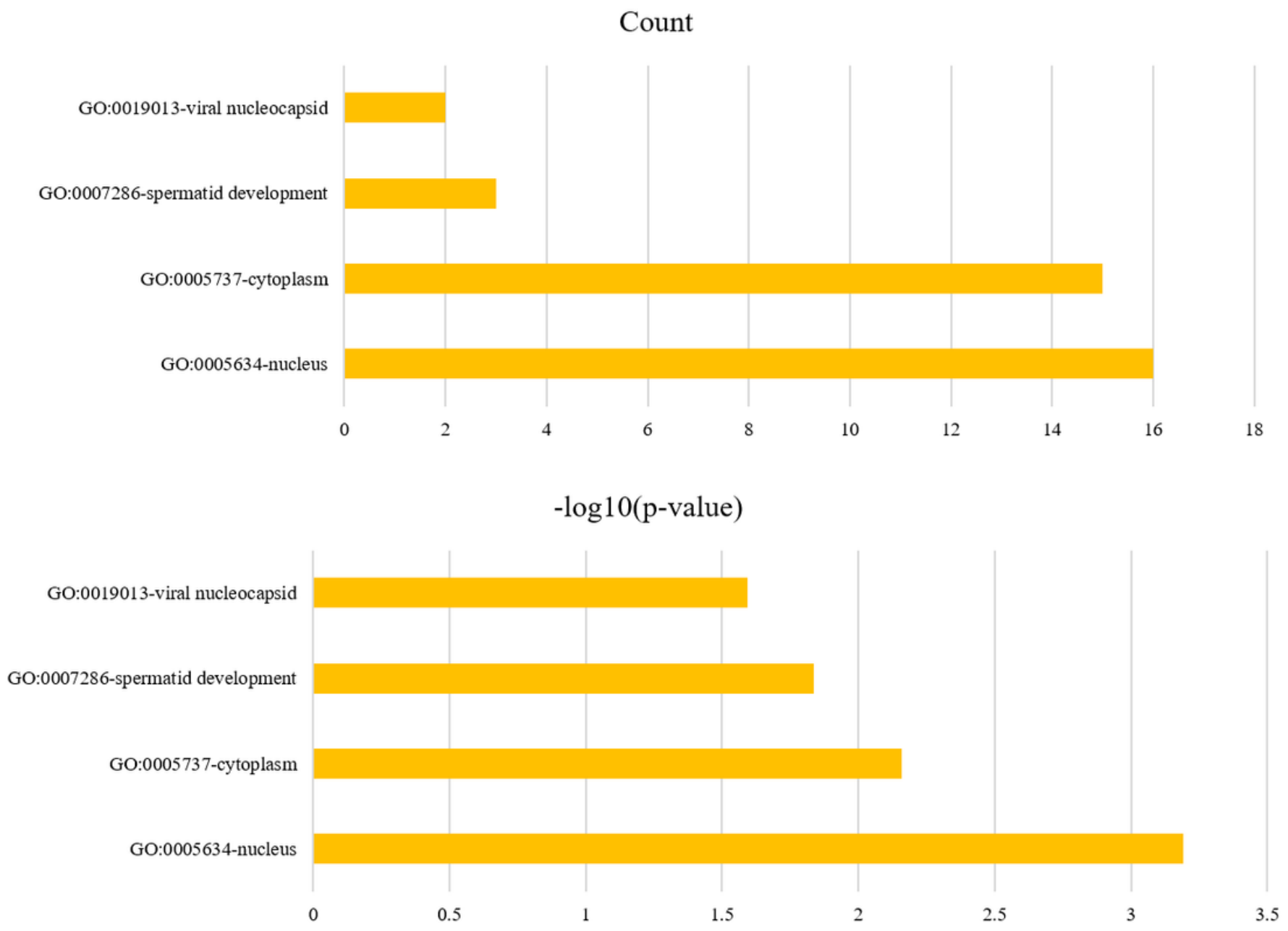

\section{Figure 4}

Differential genes GO terms functional annotation clustering Note: The vertical axis represents the name of the $\mathrm{GO}$ categories, and the horizontal axis represents the number or $\mathrm{p}$-value of the genes in the $\mathrm{GO}$ categories. 


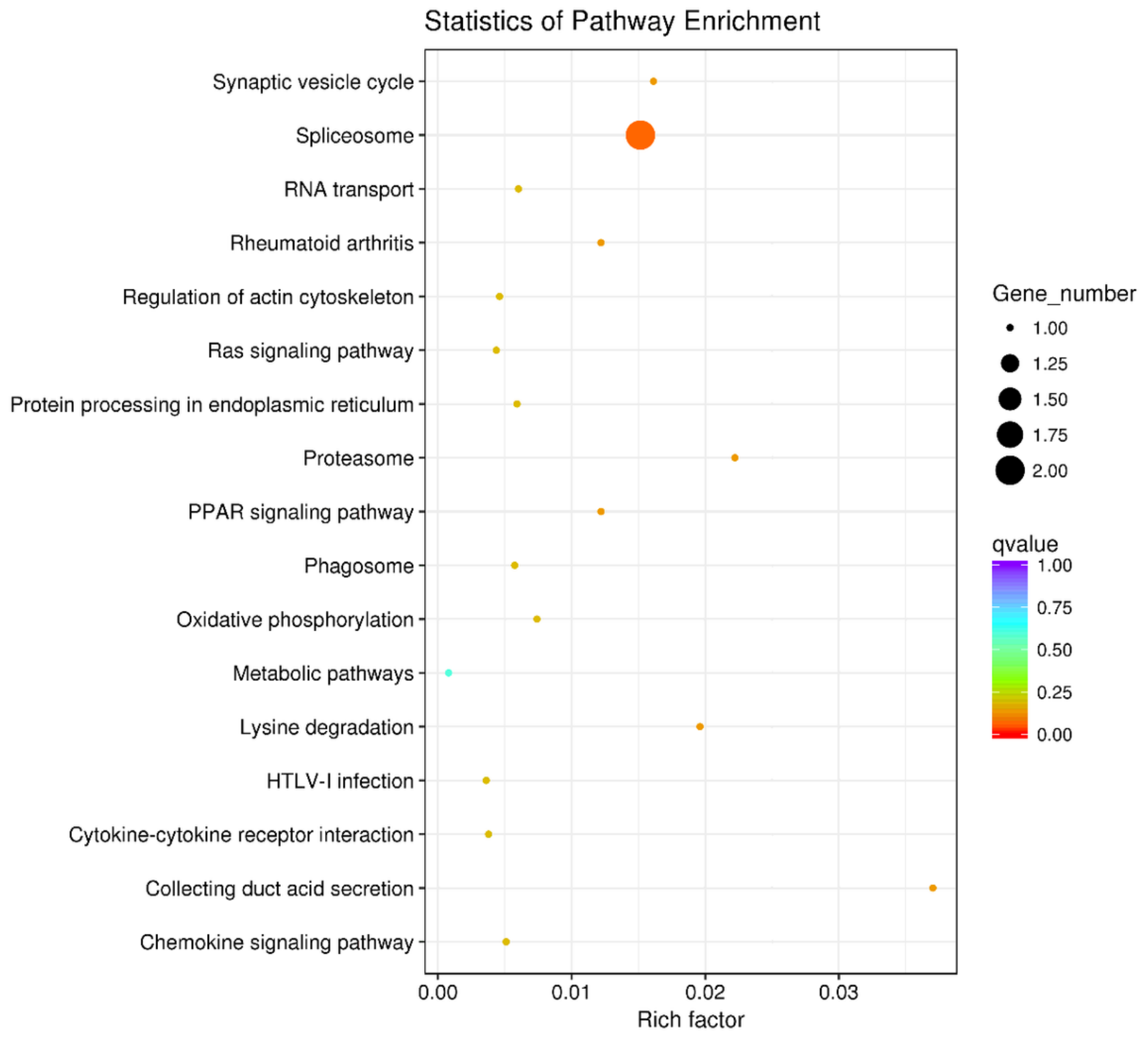

\section{Figure 5}

Differential genes KEGG enrichment Note: The vertical axis represents the name of the metabolic pathway, and the horizontal axis represents the degree of enrichment. The size of the dot indicates the number of differentially expressed genes in this pathway, and the color of the dots corresponds to a different q-value. $(n=3)$ 
Hnrnpu

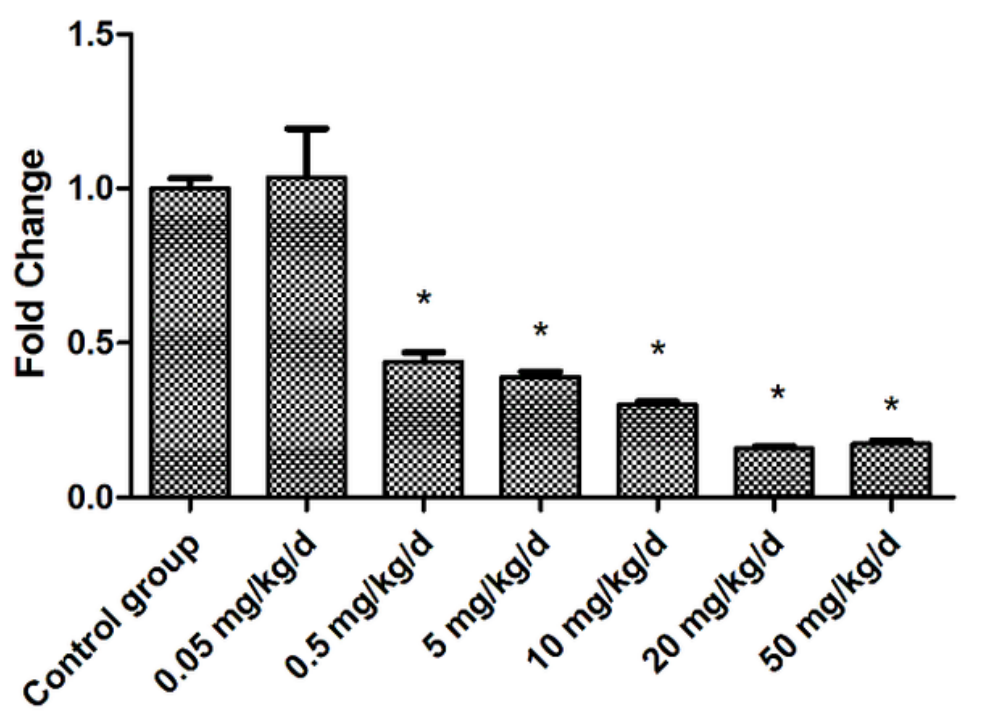

Snrpc

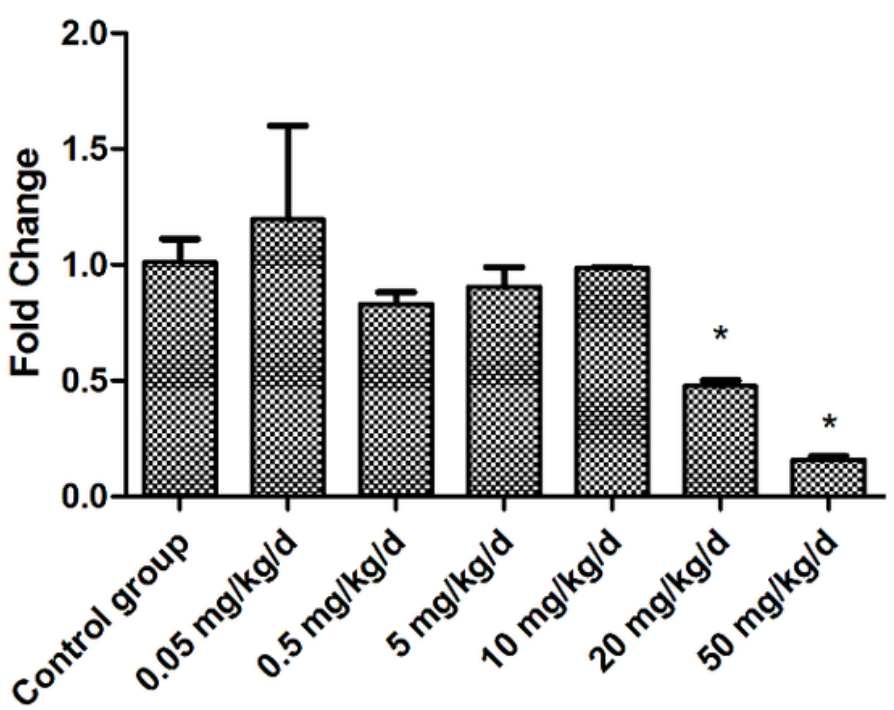

Figure 6

Relative expression levels of Snrpc and Hnrnpu genes Note: The ordinate is the differential fold change of Snrpc and Hnrnpu gene relative to the housekeeping gene ( $\beta$-actin), and the abscissa is the seven groups established according to the exposure doses of the BPA in the experiment. " $\star$ " indicate significant difference $(P<0.05) . n=3$ 